\title{
Relationships between severity of signs and symptoms and quality of life in patients with chronic venous disease
}

\author{
Estudo da relação entre a gravidade dos sinais, dos sintomas e da qualidade de vida em \\ pacientes portadores de doença venosa crônica
}

Fabio Henrique Rossi', Marília Granzotto Volpato', Patrick Bastos Metzger', Camila Baumann Beteli', Bruno Lourenção de Almeida', Cybelle Bossolani Onofre Rossi', Nilo Mitsuru Izukawa'

\begin{abstract}
Background: Chronic venous disease (CVD) is progressive and has a high prevalence in the economically active population. Its impact on the quality of life of affected individuals is poorly understood. Objective: To test for correlations between the CEAP classification of CVD severity and CVD symptoms and quality of life of affected individuals. Methods: We investigated 91 lower limbs in 59 patients with CVD (CEAP C1- C6). Patients were assessed with a Visual Analogue Pain Scale (VAPS), the Venous Clinical Severity Score (VCSS) and the SF-36 quality-of-life questionnaire. Spearman correlation coefficients were calculated. Results: There were positive correlations between the CEAP classification and scores for VAPS (0.815, p <0.000), VCSS (0.937, p <0.000), and SF-36 in the dimensions Physical Functioning: -0.791, $p<0.000$; Role Physical: -0.839 ; $p<0.000$; Bodily Pain: -0.684 ; General Health: -0.617 , $p<0.000$; Role Emotional: $-0.691, p<0.000$ ). There was no correlation with Vitality: $-0.003, p=0.979$; Role Social: -0.188 , $p=0.740$ or Mental Health: $-0.085, p=0.421$. Conclusions: There were positive correlations between CEAP and both VAPS and VCSS. Chronic Venous Insufficiency progressively affects quality of life (SF-36). Physical and emotional aspects are more severe at later stages of CVD. Vitality, Mental Health and Role Social can be negatively impacted from the early stages of the disease.
\end{abstract}

Keywords: varicose veins; venous insufficiency; quality of life; signs and symptoms.

\begin{abstract}
Resumo
Contexto: A doença venosa crônica (DVC) é a causa mais frequente dos sintomas vasculares que acometem os membros inferiores. É pouco estudada a relação entre seus sinais clínicos, a intensidade dos sintomas, e a qualidade de vida do indivíduo acometido. Objetivos: Verificar se existe uma relação positiva entre a progressão da doença e a gravidade dos sintomas e a piora na qualidade de vida. Métodos: Avaliamos 91 membros com classificação clínica CEAP entre C1 e C6. Os sintomas foram avaliados através da Escala Visual Analógica de Dor (EVAD), da Escala de Gravidade Clínica dos Sintomas Venosos (EGCSV) e pelo questionário de qualidade de vida SF-36. Foi verificada a presença de correlação entre essas variáveis através do método proposto por Spearman, considerando $p$ significativo quando inferior a 0,05. Resultados: Houve correlação positiva entre a gravidade da doença da DVC (CEAP C1-6) e a $\operatorname{EVAD}(0,815 ; p<0,000)$ e a EGCSV $(0,937 ; p<0,000)$; observou-se correlação negativa com a SF-36 nos quesitos: Capacidade Funcional (-0,791; $p<0,000)$; Limitação Física (-0,839; $p<0,000)$; Dor $(-0,684 ; p<0,000)$; Estado Geral de Saúde (-0,617; $p<0,000)$; Aspectos Emocionais (-0,691; $p<0,000)$. Não houve correlação com a Vitalidade $(-0,003$, $p=0,979)$, Aspectos Sociais $(-0,188, p=0,740)$ e Saúde Mental $(-0,085, p=0,421)$. Conclusões: Na DVC, existe uma correlação positiva entre a gravidade dos sinais clínicos da doença e a intensidade dos sintomas, e correlação negativa com a qualidade de vida, que é gravemente comprometida, em seus aspectos físicos e emocionais. A vitalidade, a saúde mental e os aspectos sociais são comprometidos já nos estágios iniciais da doença.
\end{abstract}

Palavras-chave: varizes; insuficiência venosa; qualidade de vida; sinais e sintomas. 


\section{BACKGROUND}

Chronic venous disease (CVD) is the most common cause of vascular symptoms affecting the lower limbs. In Europe, 15\% of adults aged 30 to 70 years have the disease and $1 \%$ have ulcers. ${ }^{1}$ In Brazil, these prevalence rates are $53.5 \%$ and $1.5 \%$ respectively and advanced forms of CVD are the 14th most frequent cause of absence from work. ${ }^{2,3}$ The disease is a severe public health problem, both in view of its high prevalence and its socioeconomic impacts. ${ }^{4}$

Despite its high prevalence and severity, little is known about the intensity of the symptoms of CVD or their impact on quality of life at the different stages of its clinical course. Telangiectasias and varicose veins of the lower limbs are common causes of medical consultations, particularly in tropical countries. ${ }^{4,5}$ However, it is very common for treatment of this disease to be relegated to a low priority or even refused by public and supplementary health services, with the argument that the complaint is merely cosmetic. Apparently, social, environmental, cultural, epigenetic and economic factors have an influence on this correlation. ${ }^{6}$

Both the complaints and the symptoms of CVD have chronic, subjective and periodic characteristics. Pain is not always the most important symptom. Feelings of heaviness, itching, cramps and other symptoms can also be reported, which can make diagnosis more difficult and delay the correct treatment in up to $40 \%$ of cases. ${ }^{4}$

As the pathophysiologic mechanisms of CVD have come to be better understood and the CEAP classification has become better known, diagnosis rates have risen and the disease has become better understood. ${ }^{7}$ However, few studies have attempted to correlate the severity of clinical signs and disease progression with the changing symptoms and the impact on patients' quality of life. ${ }^{8-14}$ Of those studies that have been conducted, some have detected a positive correlation, ${ }^{9,14-16}$ but others have reported a negative relationship..$^{17,18}$

The objective of this study was to determine whether there is a correlation between severity of clinical signs of CVD (according to the CEAP classification) and the results of a Visual Analogue Pain Scale (VAPS), the results of the Venous Clinical Severity Score (VCSS) and Quality of Life, as measured by the Brazilian version of the SF-36.

\section{METHODS}

This was a prospective study of a sample of 59 patients with a total of 91 limbs affected by CVD, with CEAP classifications ranging from $\mathrm{C} 1$ to $\mathrm{C} 6$, recruited at a Venous Diseases Clinic. The study protocol was approved by the Hospital's Research Ethics Committee.

In addition to the patients' demographic data, the study also collected and analyzed data on severity of clinical signs of CVD, CVD symptoms and patient quality of life, using the following instruments and scales:

1. Classification of CVD severity :

a. Classification of clinical signs of CEAP ${ }^{19}$ :

i. C1: Telangiectasies or reticular veins.

ii. C2: Varicose veins.

iii. C3: Edema.

iv. C4: Lipodermatosclerosis.

v. C5: Healed venous ulcer .

vi. C6: Active venous ulcer .

2. Visual Analogue Pain Scale (VAPS): patients indicate the maximum intensity of pain or similar complaint that their disease is causing on a visual scale running from ' 0 to 10 ', on which zero signifies absence of pain and ten indicates the greatest degree of pain that is bearable..$^{20,21}$

3. Venous Clinical Severity Score (VCSS): The CVD classification system proposed by the American Venous Forum consists of ten clinical descriptors (pain, varicose veins, edema, stasis dermatitis, lipodermatosclerosis, inflammation, presence and diameter of ulcers and time in activity, and use of compression therapy). Each descriptor is scored from 0 to 3 (giving a maximum score of 30). The scale indicates the severity of CVD and can be used to assess response to treatment. ${ }^{22}$

4. Generic health status questionnaire, the Medical Outcomes Study - 36-Item Short-Form Health Survey (SF-36). This instrument comprises 36 items that assess health-related quality of life in eight domains. Four domains relate to physical health, as follows: physical function, role physical, bodily pain, general health. The other four domains relate to mental factors, as follows: vitality, role social, role emotional and mental health. Each item is scored from 0 to 100 , where 0 indicates the worst possible situation and 100 indicates the best. ${ }^{14} \mathrm{We}$ employed the online questionnaire available at: http://www. sf-36.org/demos/SF-36.html. 
The hypothesis to be tested was that there would be positive correlations between the CEAP classification of clinical signs and the instruments described above for assessment of pain (VAPS), severity of the venous symptoms (VCSS) and quality of life (SF-36). Spearman correlation coefficients were calculated and $p$ values were considered indicative of significance when below 0.05 .

\section{RESULTS}

A total of 59 patients seen consecutively at the Venous Diseases Clinic were enrolled. These patients had a total of 91 limbs exhibiting clinical signs of CVD. These were categorized according to the CEAP classification and the resulting distribution is shown in Table 1.

Table 2 lists demographic characteristics and risk factors for CVD, showing that the sample was adequately homogenous.

In 49 limbs $(53.8 \%)$, the patient's primary complaint was pain; in $20(21.9 \%)$ it was sensation of heaviness; in 12 (13.2\%) it was a burning feeling; in $5(5.5 \%)$ it was cramps and in $5(5.5 \%)$ limbs

Table 1. CEAP scores for limbs with chronic venous disease $(\mathrm{N}=91)$.

\begin{tabular}{ccc}
\hline CEAP & N & $\%$ \\
\hline 1 & 22 & 24.7 \\
2 & 23 & 25.3 \\
3 & 10 & 10.7 \\
4 & 11 & 12 \\
5 & 10 & 10.9 \\
6 & 15 & 16.5 \\
Total & 91 & 100 \\
\hline
\end{tabular}

the primary complaint was fatigue. Each of these symptoms were considered equivalents of pain and their intensity was classified on the VAPS. Infection or inflammation (cellulitis, venous eczema, erysipelas or lymphangitis) was detected in $78 \%$ of patients with a CEAP classification of C5-6.

There were positive correlations between CEAP clinical classification and both the VAPS and the VCSS results(Table 3).

It was also observed that there was a negative correlation between clinical signs of the disease (CEAP classification) and the results of the SF-36 quality-of-life questionnaire, particularly with regard to physical factors, as follows: Physical Functioning: $-0.791, \mathrm{p}<0.000$; Role Physical: $-0.839, \mathrm{p}<0.000$; Bodily Pain: -0.684 ; and General Health: -0.617 ; $\mathrm{p}<0.000$. Among the mental and social domains, there was a positive correlation with Role Emotional: $-0.691 ; p<0.000$, but there was no correlation with Vitality: $-0.003, p=0.979$; Role Social: -0.188 , $\mathrm{p}=0.740$, or Mental Health: $-0.085, \mathrm{p}=0.421$ (Table 4; Figure 1).

\section{DISCUSSION}

The objective of classifying CVD severity (using the CEAP scale) is to standardize assessments and improve understanding of the disease's clinical course. ${ }^{19}$ However, this classification does not quantify or qualify symptoms, it simply records their presence on the basis of observation of the clinical signs exhibited by the limb. A positive correlation has been demonstrated between the severity of these signs in individuals with CVD and the severity of reflux and/or obstruction seen on color Doppler venous ultrasonography. ${ }^{19,23,24}$

Table 2. Demographic characteristics of patients by CEAP classification of clinical signs.

\begin{tabular}{|c|c|c|c|c|c|c|c|c|}
\hline & CEAP & 1 & 2 & 3 & 4 & 5 & 6 & $\mathrm{p}$ \\
\hline \multirow[t]{2}{*}{ Age } & Mean & 44 & 39 & 43 & 45 & 62 & 68 & 0.34 \\
\hline & SD & 14.3 & 5.4 & 13.7 & 11.3 & 5.7 & 8.1 & \\
\hline Female (\%) & & 98 & 100 & 89 & 78 & 89 & 78 & 0.28 \\
\hline Skin color (\%) & & & & & & & & 0.23 \\
\hline White & & 67 & 70 & 80 & 56 & 52 & 63 & \\
\hline Brown & & 21 & 26 & 12 & 32 & 38 & 30 & \\
\hline Black & & 12 & 4 & 8 & 12 & 38 & 7 & \\
\hline \multirow[t]{2}{*}{ BMI } & Mean & 23.4 & 24.7 & 25.7 & 26.2 & 27.8 & 35.6 & 0.16 \\
\hline & SD & 3.4 & 5 & 4.2 & 6 & 8 & 6 & \\
\hline HC (\%) & & 29 & 34 & 23 & 25 & 20 & 11 & 0.12 \\
\hline HRT (\%) & & 2 & 4 & 12 & 8 & 7 & 1 & 0.34 \\
\hline Obesity (\%) & & 8 & 5 & 6 & 12 & 27 & 23 & 0.11 \\
\hline DVT (\%) & & 0 & 0 & 1.3 & 2.2 & 3.4 & 2 & 0.12 \\
\hline Smoking (\%) & & 5 & 2.2 & 12.1 & 6.2 & 4.1 & 10 & 0.15 \\
\hline
\end{tabular}

BMI: body mass index. HC: hormonal contraceptive. HRT: hormone replacement therapy. DVT: history of DVT; $p$ : according to Student's test for paired observations. 
Table 3. Correlations between CEAP classification and results for Visual Analogue Pain Scale (VAPS) and Venous Clinical Severity Score (VCSS)

\begin{tabular}{|c|c|c|c|c|c|c|c|c|c|}
\hline & CEAP & 1 & 2 & 3 & 4 & 5 & 6 & SCC & $p$ \\
\hline & $\mathrm{N}$ & 22 & 23 & 10 & 11 & 10 & 15 & & \\
\hline \multirow[t]{2}{*}{ VAPS } & Mean & 1.2 & 2.3 & 3.4 & 5.3 & 6.3 & 7.4 & 0.815 & 0.000 \\
\hline & SD & 1.2 & 1.3 & 2.5 & 1.7 & 2.3 & 2.2 & & \\
\hline \multirow[t]{2}{*}{ VCSS } & Mean & 3.3 & 6.4 & 11.6 & 16.1 & 18 & 22.3 & 0.937 & 0.000 \\
\hline & SD & 2.6 & 3.9 & 3.4 & 3.5 & 3.6 & 4.6 & & \\
\hline
\end{tabular}

SD: standard Deviation. SCC: Spearman Correlation Coefficient. VAPS: Visual Analogue Pain Scale. VCSS: Venous Clinical Severity Score.

Table 4. Correlation between CEAP clinical classification and the SF-36 Quality of life questionnaire domains.

\begin{tabular}{|c|c|c|c|c|c|c|c|c|c|}
\hline & CEAP & 1 & 2 & 3 & 4 & 5 & 6 & SCC & $\mathrm{p}$ \\
\hline & $\mathrm{N}$ & 22 & 23 & 10 & 11 & 10 & 15 & & \\
\hline Physical & Mean & 97.7 & 95.6 & 52.4 & 59.7 & 45.6 & 50,1 & -0.791 & 0.000 \\
\hline Functioning & SD & 5.0 & 8 & 29.6 & 21.2 & 15.5 & 14.3 & & \\
\hline Role & Mean & 99.5 & 95 & 48 & 54.5 & 51 & 22.9 & -0.839 & 0.000 \\
\hline Physical & SD & 2.1 & 9.6 & 28.9 & 21.5 & 11 & 16.5 & & \\
\hline Bodily & Mean & 81.4 & 63.6 & 55.2 & 61.6 & 48.2 & 44.2 & -0.684 & 0.000 \\
\hline Pain & SD & 13.6 & 18.2 & 17.9 & 16.4 & 10.9 & 8.28 & & \\
\hline General & Mean & 86.9 & 70.87 & 69.3 & 61.6 & 62.9 & 51 & -0.617 & 0.000 \\
\hline Health & SD & 14.3 & 13.4 & 15.4 & 19.5 & 6 & 14.1 & & \\
\hline \multirow[t]{2}{*}{ Vitality } & Mean & 61.4 & 53.3 & 62.3 & 64.2 & 64.8 & 51 & -0.003 & 0.979 \\
\hline & SD & 18.8 & 15.1 & 15.3 & 17.9 & 14.2 & 10.9 & & \\
\hline Role & Mean & 96.9 & 83.7 & 52.7 & 65.3 & 59.4 & 51 &,- 691 & 0.000 \\
\hline Emotional & SD & 9.7 & 21.5 & 38.9 & 20.5 & 25 & 18.2 & & \\
\hline Role & Mean & 62.5 & 63.4 & 58.8 & 65.2 & 65.1 & 46.6 & -0.188 & 0.740 \\
\hline Social & SD & 18.9 & 15.5 & 24.3 & 21.3 & 14.6 & 15.7 & & \\
\hline Mental & Mean & 69.4 & 64.8 & 64.4 & 68.7 & 63.6 & 62.8 &,- 0850 & 0.421 \\
\hline Health & SD & 14.53 & 15 & 21.7 & 16.9 & 13.7 & 16.2 & & \\
\hline
\end{tabular}

N: number of limbs. SCC: Spearman Correlation Coefficient. SD: standard Deviation.

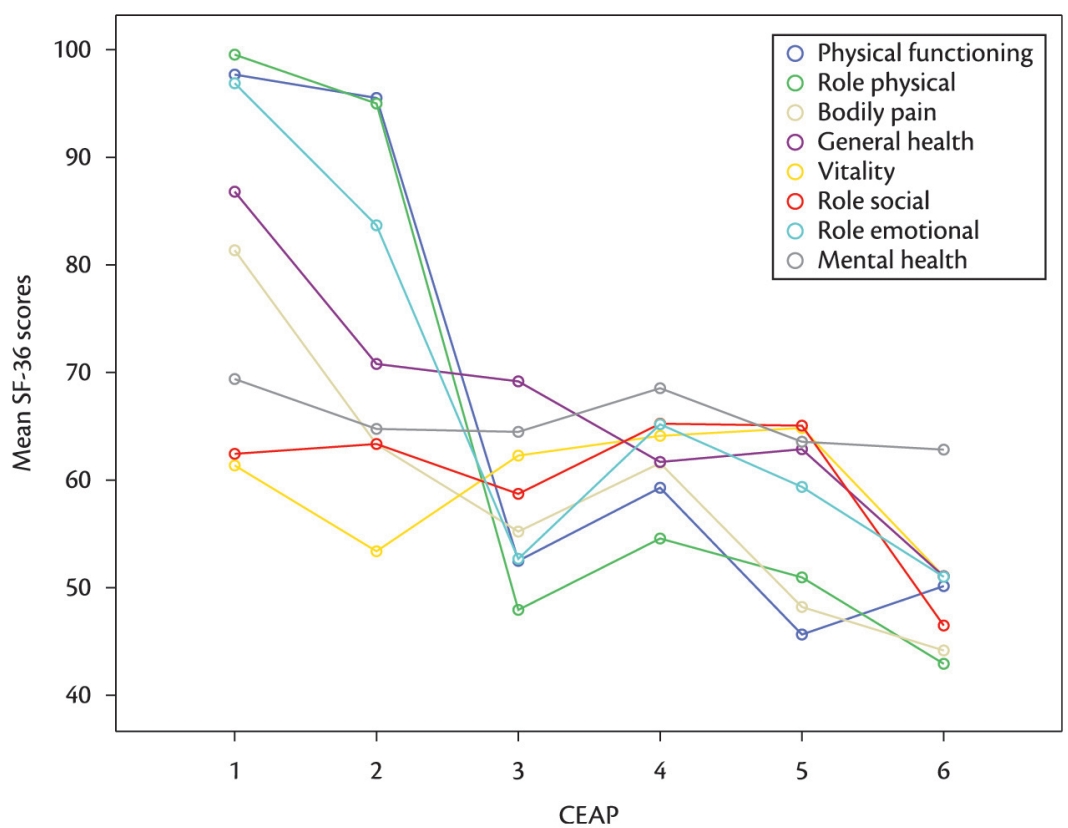

Figure 1. Correlation between CEAP classification (C1-6) and means for physical and mental domains of SF-36 quality of life questionnaire. 
The symptom pain is not always present in CVD. In our study, this symptom was present in 53.8\% of cases. The principal complaint is very often described as a sensation of heaviness, burning, fatigue or cramp, etc. This can confound diagnosis, delay referral of the patient to a specialist and serve as a barrier to accessing treatment. Additionally, even though these symptoms can be a significant cause of discomfort and reduced quality of life, few studies have investigated the intensity of CVD symptoms and its impact on quality of life. . $^{10,11,14-}$ 18,25 The majority of studies that have investigated these factors have been conducted in countries with temperate climates, with a predominance of cold days, where limbs are exposed less frequently; with the result that there are fewer esthetic concerns, which contrasts with the situation in countries with tropical climates. Notwithstanding, it has been shown that affected individuals can suffer functional limitations to quality of life, even during the initial stages of the disease. ${ }^{26}$

In our study we evaluated presence of symptoms using a VAPS ${ }^{20,21}$ and the VCSS classification system proposed by the American Venous Forum. ${ }^{27}$

Was observed that there was a positive correlation between clinical signs (CEAP) of CVD and the results of the VAPS and VCSS. Other studies have not reported the same results. Bradbury et al ${ }^{15}$ studied a population of $1500 \mathrm{CVD}$ patients aged 18 to 64 years and find a low correlation between quantity of truncular varicose veins and presence of pain, irrespective of sex. ${ }^{15}$ Howlader et al. found that mean VAPS scores were 2.8 for CEAP C2; 4.5 for CEAP $\mathrm{C} 3$, just 0.5 for CEAP C4, and 0.0 for CEAP C5 ${ }^{25}$ In the present study, the means for CEAP C2 and $\mathrm{C} 3$ were very similar to these; however, the mean scores for CEAP C4, C5 and C6 were all higher.

These contrasting findings can be explained by a series of theories on the pathophysiological mechanisms of pain. Apparently, patients with advanced CVT exhibit changes to the sensory innervation of venous walls, secondary to microangiopathic venous ischemia and increased endoneurial venous pressure. ${ }^{28,29}$ Additionally, demographic sociocultural, environmental and epigenetic factors ${ }^{30}$ and presence of inflammation or infection ${ }^{31,32}$ can also have an impact on the intensity of symptoms. The sample analyzed here exhibits certain peculiarities: invariably these patients were living in poor socioeconomic and cultural conditions and $78 \%$ of cases with CEAP classifications of C5-C6 had commitment infections, which is a condition that is known to be related to inflammation and increased pain intensity. Furthermore, these patients were recruited at a CVD clinic where only those patients who continue to exhibit symptoms are scheduled to return for further outpatients consultations.

There was a negative correlation between CEAP classification and the majority of the domains on the SF-36 quality of life questionnaire, as follows: Physical Functioning, Role Physical, Bodily Pain, General Health and Role Emotional. The more advanced the disease, the greater the degree of compromise in these dimensions.

There were no correlations with the dimensions Vitality, Role Social or Mental Health. This was because these dimensions were already negatively impacted at initial stages of the disease. The sensation of heaviness limiting daily activities, embarrassment with relation to exposing limbs and nervousness were constant complaints observed right from the initial stages of the disease in this study. These results coincide with findings reported by Andreozzi et al. ${ }^{12}$, who showed that physical and emotional dimensions are already compromised in the initial stages of this disease (CEAP C1-3). It is of interest to note that the same authors found that at more advanced stages the profile of quality-of-life compromise is similar to what is observed in diseases considered to be more serious, such as diabetes, cancer, chronic obstructive pulmonary disease and even heart failure. ${ }^{12}$ A similar study, conducted in San Diego, United States, with 2,257 University employees also observed significant reductions in quality of life, specifically in the physical dimensions, but not in the mental dimensions ${ }^{33}$ Here in Brazil, Santos et al. also observed progressive compromise of quality of life among patients with CVD. ${ }^{14}$

This study is subject to certain limitations related to the patient sample. Patients who are treated at public hospitals very often only manage to access medical care when they are highly symptomatic or have reached more severe stages of disease. Population-based cohort studies are needed in order to arrive at a better understanding of the correlations between clinical signs of CVD, symptoms and quality of life.

The data discussed here demonstrate the complex pathophysiology and the importance of the influence of environmental aspects and socioeconomic and cultural factors on the clinical course of CVD. However, there is no longer any doubt with relation to the significant loss of quality-of-life that can be observed right from the earliest stages of the disease. 


\section{CONCLUSIONS}

In this sample of patients with CVD, there was a positive correlation between severity of clinical signs and intensity of symptoms and a negative correlation with quality-of-life, which was severely compromised in both physical and emotional dimensions. Vitality, Mental Health and Role Social can be negatively impacted from the very earliest stages of the disease. Population-based cohort studies should be conducted in order to arrive at a better understanding of the correlations between clinical signs of CVD, symptoms and quality of life.

\section{REFERENCES}

1. Heit JA, Rooke TW, Silverstein MD, Mohr DN, Lohse CM, Petterson $\mathrm{TM}$, et al. Trends in the incidence of venous stasis syndrome and venous ulcer: a 25-year population-based study. J Vasc Surg. 2001;33(5):1022-7. http://dx.doi.org/10.1067/mva.2001.113308. PMid:11331844

2. Maffei FH, Magaldi C, Pinho SZ, Lastoria S, Pinho W, Yoshida $W B$, et al. Varicose veins and chronic venous insufficiency in Brazil: prevalence among 1755 inhabitants of a country town. Int J Epidemiol. 1986;15(2):210-7. http://dx.doi.org/10.1093/ ije/15.2.210. PMid:3721683

3. Silva MC. Chronic venous insufficiency of the lower limbs and its socio-economic significance. Int Angiol. 1991;10(3):152-7. PMid:1765717.

4. Rabe E, Pannier F. Societal costs of chronic venous disease in CEAP C4, C5, C6 disease. Phlebology. 2010;25(Suppl 1):64-7. http:// dx.doi.org/10.1258/phleb.2010.010s09. PMid:20870821

5. Castro AA, Santos M. ALSC, Teixeira AR. Diagnóstico e tratamento da doença venosa crônica. J Vasc Bras. 2005;4(Supl 2):S185-94.

6. Lozano Sánchez FS, Sánchez Nevarez I, González-Porras JR, Marinello Roura J, Escudero Rodríguez JR, Díaz Sánchez S, et al. Quality of life in patients with chronic venous disease: influence of the socio-demographical and clinical factors. Int Angiol. 2013;32(4):433-41. PMid:23822947.

7. Kibbe MR, Ujiki M, Goodwin AL, Eskandari M, Yao J, Matsumura J. Iliac vein compression in an asymptomatic patient population. J Vasc Surg. 2004;39(5):937-43. http://dx.doi.org/10.1016/j. jvs.2003.12.032. PMid:15111841

8. Lamping DL. Measuring health-related quality of life in venous disease: practical and scientific considerations. Angiology. 1997;48(1):51-7. http://dx.doi.org/10.1177/000331979704800109. PMid:8995344

9. Garratt AM, Ruta DA, Abdalla MI, Russell IT. Responsiveness of the SF-36 and a condition-specific measure of health for patients with varicose veins. Qual Life Res. 1996;5(2):223-34. http://dx.doi. org/10.1007/BF00434744. PMid:8998491

10. Launois R, Reboul-Marty J, Henry B. Construction and validation of a quality of life questionnaire in chronic lower limb venous insufficiency (CIVIQ). Qual Life Res. 1996;5(6):539-54. http:// dx.doi.org/10.1007/BF00439228. PMid:8993100

11. Kurz X, Lamping DL, Kahn SR, Baccaglini U, Zuccarelli F, Spreafico $G$, et al. Do varicose veins affect quality of life? Results of an international population-based study. J Vasc Surg. 2001;34(4):6418. http://dx.doi.org/10.1067/mva.2001.117333. PMid:11668318
12. Andreozzi GM, Cordova RM, Scomparin A, Martini R, D'Eri A, Andreozzi F. Quality of life in chronic venous insufficiency. An Italian pilot study of the Triveneto Region. Int Angiol. 2005;24(3):272-7. PMid:16158038.

13. Chiesa R, Marone EM, Limoni C, Volonté M, Schaefer E, Petrini O. Effect of chronic venous insufficiency on activities of daily living and quality of life: correlation of demographic factors with duplex ultrasonography findings. Angiology. 2007;58(4):440-9. http:// dx.doi.org/10.1177/0003319706292012. PMid:17875957

14. Santos RFFN, Porfírio GJM, Pitta GBB. A diferença na qualidade de vida de pacientes com doença venosa crônica leve e grave. J Vasc Bras. 2009;8(2):143-7. http://dx.doi.org/10.1590/ S1677-54492009000200008.

15. Bradbury A, Evans C, Allan P, Lee A, Ruckley CV, Fowkes FG. What are the symptoms of varicose veins? Edinburgh vein study cross sectional population survey. BMJ. 1999;318(7180):353-6. http:// dx.doi.org/10.1136/bmj.318.7180.353. PMid:9933194

16. Garratt AM, Macdonald LM, Ruta DA, Russell IT, Buckingham JK, Krukowski ZH. Towards measurement of outcome for patients with varicose veins. Qual Health Care. 1993;2(1):5-10. http:// dx.doi.org/10.1136/qshc.2.1.5. PMid:10132081

17. Smith JJ, Garratt AM, Guest M, Greenhalgh RM, Davies AH. Evaluating and improving health-related quality of life in patients with varicose veins. J Vasc Surg. 1999;30(4):710-9. http://dx.doi. org/10.1016/S0741-5214(99)70110-2. PMid:10514210

18. Baker DM, Turnbull NB, Pearson JC, Makin GS. How successful is varicose vein surgery? A patient outcome study following varicose vein surgery using the SF-36 Health Assessment Questionnaire. Eur J Vasc Endovasc Surg. 1995;9(3):299-304. http://dx.doi. org/10.1016/S1078-5884(05)80134-0. PMid:7620955

19. Eklöf B, Rutherford RB, Bergan JJ, Carpentier PH, Gloviczki $P$, Kistner RL, et al. Revision of the CEAP classification for chronic venous disorders: consensus statement. J Vasc Surg. 2004;40(6):1248-52. http://dx.doi.org/10.1016/j.jvs.2004.09.027. PMid: 15622385

20. Scott J, Huskisson EC. Graphic representation of pain. Pain. 1976;2(2):175-84. http://dx.doi.org/10.1016/0304-3959(76)901135. PMid: 1026900

21. Jensen MP, Karoly $P$, Braver $S$. The measurement of clinical pain intensity: a comparison of six methods. Pain. 1986; 2(2):185-90.

22. Rutherford RB, Padberg FT Jr, Comerota AJ, Kistner RL, Meissner $\mathrm{MH}$, Moneta GL. Venous severity scoring: An adjunct to venous outcome assessment. J Vasc Surg. 2000;31(6):1307-12. http:// dx.doi.org/10.1067/mva.2000.107094. PMid:10842165

23. Passman MA, McLafferty RB, Lentz MF, Nagre SB, lafrati MD, Bohannon WT, et al. Validation of Venous Clinical Severity Score (VCSS) with other venous severity assessment tools from the American Venous Forum, National Venous Screening Program. J Vasc Surg. 2011;54(S):2S-9S.

24. Gloviczki P, Comerota AJ, Dalsing MC, Eklof BG, Gillespie DL, Gloviczki $M L$, et al. The care of patients with varicose veins and associated chronic venous diseases: clinical practice guidelines of the Society for Vascular Surgery and the American Venous Forum. J Vasc Surg. 2011.53(5):2S-48S.

25. Howlader MH, Smith PDC. Symptoms of chronic venous disease and association with systemic inflammatory markers. J Vasc Surg. 2003;38(5):950-4. http://dx.doi.org/10.1016/S07415214(03)00600-1. PMid:14603199

26. Kaplan RM, Criqui MH, Denenberg JO, Bergan J, Fronek A. Quality of life in patients with chronic venous disease: San Diego population study. J Vasc Surg. 2003;37(5):1047-53. http://dx.doi. org/10.1067/mva.2003.168. PMid:12756353 
27. Vasquez MA, Rabe E, McLafferty RB, Shortell CK, Marston WA, Gillespie $D$, et al. Revision of the venous clinical severity score: venous outcomes consensus statement: special communication of the American Venous Forum Ad Hoc Outcomes Working Group. J Vasc Surg. 2010;52(5):1387-96. http://dx.doi.org/10.1016/j. jvs.2010.06.161. PMid:20875713

28. Padberg FT Jr, Maniker AH, Carmel G, Pappas PJ, Silva MB Jr, Hobson RW 2nd. Sensory impairment: a feature of chronic venous insufficiency.J Vasc Surg. 1999;30(5):836-42. http://dx.doi. org/10.1016/S0741-5214(99)70008-X. PMid:10550181

29. Reinhardt F, Wetzel T, Vetten S, Radespiel-Tröger M, Hilz MJ, Heuss $D$, et al. Peripheral neuropathy in chronic venous insufficiency. Muscle Nerve. 2000;23(6):883-7. http://dx.doi.org/10.1002/ (SICI)1097-4598(200006)23:6<883::AID-MUS6>3.0.CO;2-T. PMid:10842263

30. Zubieta JK, Heitzeg MM, Smith YR, Bueller JA, Xu K, Xu Y, et al. COMT val158met genotype affects mu-opioid neurotransmitter responses to a pain stressor. Science. 2003;299(5610):1240-3. http://dx.doi.org/10.1126/science.1078546. PMid:12595695

31. Holthusen $\mathrm{H}$. Involvement of the NO/cyclic GMP pathway in bradykinin-evoked pain from veins in humans. Pain. 1997;69(12):87-92. http://dx.doi.org/10.1016/S0304-3959(96)03262-9. PMid:9060017

32. Raffetto JD. Inflammation in chronic venous ulcers. Phlebology. 2013;28(Suppl 1):61-7. http://dx.doi. org/10.1177/0268355513476844. PMid:23482537

33. Kaplan RM, Criqui MH, Denenberg JO, Bergan J, Fronek A. Quality of life in patients with chronic venous disease: San Diego population study. J Vasc Surg. 2003;37(5):1047-53. http://dx.doi. org/10.1067/mva.2003.168. PMid:12756353
Correspondence

Fabio Henrique Rossi

Av. Dr. Dante Pazzanese, 500, Vila Mariana CEP 04012-909 - São Paulo (SP), Brazil

E-mail: vascular369@hotmail.com

Author information

FHR: PhD in Medicine, School of Medicine, Universidade de São Paulo. Assistant vascular and endovascular surgeon, Instituto Dante Pazzanese de Cardiologia. MGV: Resident in Vascular and Endovascular Surgery, Instituto Dante Pazzanese de Cardiologia.

PBM: Vascular and endovascular surgeon, Instituto Dante Pazzanese de Cardiologia.

CBB: Vascular and endovascular surgeon, Instituto Dante Pazzanese de Cardiologia.

BLA: Vascular and endovascular surgeon, Instituto Dante Pazzanese de Cardiologia.

CBOR: Clinical engineer, Instituto Dante Pazzanese de Cardiologia.

NMI: PhD in Medicine, School of Medicine, Universidade de

São Paulo. Chief vascular surgeon, Instituto Dante Pazzanese de Cardiologia.

Author contributions Conception and design: FHR Analysis and interpretation: FHR, CBOR

Data collection: MGV

Writing the article: FHR

Critical revision of the article: $\mathrm{NMI}, \mathrm{CBOR}$

Final approval of the article*: FHR, MGV, PBM, CBB, BLA, CBOR, NMI Statistical analysis: FHR Overall responsibility: FHR

*All authors have read and approved of the final version of the article submitted to I Vasc Bras. 